\title{
Konstruksi Alat Ukur Kepemimpinan Spiritual dalam Keluarga
}

\author{
Hasna Esa Nisrina ${ }^{1}$, Muhammad Irsyad Faruq ${ }^{2}$, Rina Masruroh ${ }^{3}$, Siti Sa'adah Nurlatifah ${ }^{4 *}$, Siti Khairun Nisa ${ }^{5}$ \\ 1,2,3,4,5 Fakultas Psikologi, Universitas Islam Negeri Sunan Gunung Djati Bandung, Indonesia \\ e-mail:*ssnlatifah@gmail.com
}

\begin{tabular}{|c|c|}
\hline Abstract / Abstrak & Keywords / Kata kunci \\
\hline $\begin{array}{l}\text { This study aims to examine spiritual leadership in the context of the head of the } \\
\text { family. The spiritual leadership concept is lifted from Fry (2003) which is defined } \\
\text { as a matter that consists of values, attitudes, and behaviors needed to intrinsically } \\
\text { motivate oneself or others so that they have a sense of survival through spiritual } \\
\text { vocation and membership. The construct approach used is the modification } \\
\text { approach. The number of samples in this study amounted to } 405 \text { subjects with } \\
\text { purposive sampling. The content validation used is in the form of confirmatory } \\
\text { factor analysis (CFA). Of the five dimensions measured, there is one falling } \\
\text { dimension in testing, namely the meaning dimension. The other four dimensions, } \\
\text { namely vision, altruistic love, hope/ faith, and membership, can be measured by } 26 \\
\text { valid and reliable items based on the confirmatory factor analysis and cronbach } \\
\text { alpha test. Measuring instruments developed can be used again for further } \\
\text { research. }\end{array}$ & $\begin{array}{l}\text { Conctruction of } \\
\text { psychological } \\
\text { measurement; } \\
\text { Spiritual leadership; } \\
\text { Head of family; } \\
\text { Modification approach }\end{array}$ \\
\hline $\begin{array}{l}\text { Penelitian ini bertujuan untuk membuat alat ukur kepemimpinan spiritual dalam } \\
\text { konteks kepala keluarga. Konsep spiritual leadership diangkat dari Fry (2003) yang } \\
\text { didefinisikan sebagai suatu hal yang terdiri dari nilai-nilai, sikap, dan perilaku yang } \\
\text { diperlukan agar dapat memotivasi diri sendiri atau orang lain secara intrinsik } \\
\text { sehingga mereka memiliki rasa kelangsungan hidup melalui panggilan spiritual dan } \\
\text { keanggotaan. Pendekatan alat ukur yang digunakan adalah pendekatan modifikasi. } \\
\text { Jumlah sampel dalam penelitian ini berjumlah } 405 \text { subjek yang dipilih } \\
\text { menggunakan purposive sampling. Validasi isi yang digunakan berupa } \\
\text { confirmatory factor analysis (CFA). Dari } 5 \text { dimensi yang diukur, terdapat satu } \\
\text { dimensi yang gugur dalam pengujian, yakni dimensi meaning. Empat dimensi } \\
\text { lainya, yaitu vision, altruistic love, hope/ faith, dan membership dapat terukur oleh } \\
26 \text { item yang valid dan reliabel berdasarkan uji confirmatory factor analysis dan } \\
\text { cronbach alpha. Alat ukur yang dikembangkan ini dapat digunakan kembali untuk } \\
\text { penelitian selanjutnya. }\end{array}$ & $\begin{array}{l}\text { Konstruksi alat ukur } \\
\text { psikologi; } \\
\text { Kepemimpinan } \\
\text { spiritual; } \\
\text { Kepala keluarga; } \\
\text { Pendekatan modifikasi }\end{array}$ \\
\hline
\end{tabular}

\section{Pendahuluan}

Kepala keluarga haruslah menerapkan spiritualitas dalam memimpin suatu keluarga. Kepala keluarga tersebut dapat merupakan seorang ayah atau seorang ibu. Peran pemimpin dalam keluarga yang menerapkan nilai spiritualitas sangat penting, karena nilai-nilai dalam spiritualitas merupakan suatu pondasi yang menentukan kualitas suatu keluarga (Kardinah, 2009). Seorang kepala keluarga mengarahkan dan mengajarkan setiap anggota dalam keluarga untuk menerapkan dan menjalankan nilai dan norma yang dijunjung tinggi di masyarakat (Mediawati dkk., 2012). Jika kepala keluarga tidak menjalankan perannya dengan baik, maka akan menimbulkan beberapa permasalahan dalam keluarga, seperti perceraian dan kekerasan dalam rumah tangga
(Bastaits dkk., 2018; Smith-Greenaway \& Clark, 2017; Stokkebekk dkk., 2019). Sehingga menjadi penting ketika keluarga dipimpin oleh individu yang mempunyai karakter spiritualitas tinggi.

Konsep spiritualitas sendiri sudah banyak dikembangkan oleh banyak ahli yang kemudian diasumsikan sebagai suatu keadaan dimana individu menyadari bahwa dirinya adalah milik Tuhannya (Fridayanti, 2015). Perspektif tersebut muncul ke dalam permukaan hidup individu dan dimanifestasikan dalam beragam perilaku yang semuanya berfokus pada pencarian makna hidup dan keseimbangan jiwa individu (Jaenudin \& Tahrir, 2019; Ramdani dkk., 2018; Royanulloh \& Komari, 2019; Sumanty dkk., 2018). Kesadaran-kesadaran tersebutlah yang kemudian menciptakan suatu motivasi intrinsik 
bagi seseorang untuk tumbuh menjadi individu yang baik bagi orang di sekitarnya. Hal inilah yang kemudian dianggap penting bahwa keluarga harus menjadi teladan yang baik bagi yang lainnya sebagaimana dijelaskan mengenai fungsi keluarga di dalam menciptakan kehidupan anggotanya menjadi lebih bahagia.

Perkembangan konsep spiritualitas memang bisa digunakan dalam beragam konteks dan fenomena, sehingga tidak salah kalau banyak penelitian yang menginformasikan bahwa spiritualitas ini diperlukan dalam berbagai locus, seperti dalam pekerjaan, kesehatan bersama, interaksi sosial antara individu hingga yang paling menarik saat ini adalah spiritualitas dalam konteks kepemimpinan. Sejak Fry (2003) menjelaskan konsep spiritual leadership sebagai transformasi organisasi yang berkelanjutan, semenjak itulah banyak penelitian yang mencoba mendukung asumsi tersebut. Konsep yang dikembangkan oleh Fry (2003) membagi kepemimpinan spiritual menjadi 5 dimensi yang meliputi vision, altruistic love, hopel faith, meaning dan membership. Vision adalah karakteristik penting individu yang dimanifestasikan dalam kemampuan menganalisis dan memprediksi langkah-langkah yang dilakukan guna mencapai tujuan bersama. Altruistic love adalah dimensi emosional yang menjadikan seorang pemimpin peduli dan empati dengan anggotanya. Dimensi hope/ faith juga dianggap sebagai dimensi yang penting karena mampu mendorong perilakuperilaku yang sudah direncanakan menuju aksiaksi yang nyata dan penuh keberanian. Meaning adalah konsep yang sangat mendalam dimana individu menyadari bahwa mereka mempunyai kewajiban dalam mengarahkan. Sedangkan dimensi lainnya yaitu membership meliputi keterkaitan individu satu dengan yang lainnya dalam mencapai tujuan organisasi.

Sejatinya konsep kepemimpinan spiritual selalu melibatkan nilai, sikap, dan perilaku yang mengarahkan pada motivasi intrinsik seseorang untuk terlibat dengan dirinya dan orang lain dimana menimbulkan suatu pengalaman spiritual dan bermakna dalam hidup merela (Fry dkk., 2005). Perasaan seperti itulah yang kemudian menciptakan rasa, apresiasi, dan rasa memiliki seseorang sebagai pemimpin terhadap orang lain yang dipimpinnya (Afsar dkk., 2016; Benefiel, 2005; Fry dkk., 2005). Penelitian tentang kepemimpinan spiritualitas terjadi dalam berbagai konteks saat ini. Tkaczynski \& Arli (2018) melakukan penegasan tentang pentingnya sosok pemimpin spiritual yang dibutuhkan dalam menciptakan kebijakan bersama yang memperhatikan banyak hal, terutama konsepnya tersebut dikhususkan dalam agama Kristen. Sedangkan studi lainnya berfokus pada kepemimpinan spiritual yang dibangun oleh pihak sekolah untuk mengajarkan bagaimana siswa di sekolah dapat memahami setiap fenomena yang terjadi sebagai bagian dari kehebatan Tuhan dan takdirnya (Polat, 2011). Kepemimpinan yang bersifat spiritual adalah mereka yang cerdas dalam mempraktekkan halhal positif di sekelilingnya (Saad dkk., 2015), mengajak lingkungan sekitar untuk aktif bersama membangun kesadaran positif (Weinberg \& Locander, 2014), meningkatkan kepedulian dan menciptakan individu yang bermoral (Doehring, 2019), serta mereka yang mampu menciptakan keadilan yang hakiki tanpa melihat perbedaan dan latar belakang pada individu (Šilingienė \& Škèrienè, 2015).

Adapun perkembangan alat ukur spiritual leadership masih difokuskan pada aspek-aspek yang terjadi pada tataran pekerjaan dan penilaian sehingga instrumen tersebut dibuat untuk menilai apakah seorang pegawai memiliki konstruk tersebut atau tidak (Chen \& Li, 2013). Pengembangan alat ukur lainnya juga difokuskan pada konteks pendidikan dimana alat ukur tersebut digunakan sebagai instrumen untuk melihat kekuatan dari pemimpin spiritual dengan keterikatan para siswa pada sekolahnya (Kaya, 2015). Adapun yang dilakukan oleh Ayranci dan Semercioz (2011) ialah membuat alat ukur bersifat general untuk melihat konsistensi dari karyawan dan produktivitas serta hubungan mereka dengan pegawai lainnya.

Di Indonesia sendiri, perkembangan konsep pemimpin spiritual hanya difokuskan pada sejauhmana konsep tersebut menjadi penentu aspek psikologis lainnya yang masih relevan, 
namun tidak ada yang secara komprehensif melakukan spesifikasi ilmiah tentang gambaran konsep tersebut. Penelitian lainnya menekankan bahwa konsep pemimpin yang spiritual itu sejalan dengan konsep agama yang dianutnya atau yang lebih mengedepankan kepentingan bersama di dalamnya (Krisharyuli dkk., 2020). Hal ini tentu sangat terkait dengan apa yang diajarkan dalam keluarga yaitu pola asuh yang agamis, senantiasa memberikan pengasuhan yang multiperspektif terhadap anak, sehingga mereka mendampingi anak-anaknya dengan penuh kebahagiaan dan kesejahteraan (Wita dkk., 2018).

Berdasarkan hasil wawancara tidak terstruktur yang peneliti lakukan terhadap beberapa responden awal yang terlibat dalam penelitian, spiritual leadership sangat penting dimiliki oleh kepala keluarga. Pernyataan tersebut didasarkan pada beberapa alasan. Pertama, kepala keluarga diibaratkan sebagai nakhoda dalam kapal. Artinya, laju rumah tangga akan selamat sampai tujuan atau tidak, hal itu tergantung pada kepala keluarga. Kedua, membimbing keluarga dengan menerapkan nilai-nilai ajaran agama (nilai spiritual) dan menjalankannya dengan konsisten merupakan modal keselamatan serta kebahagiaan di dunia dan akhirat. Ketiga, kehidupan keluarga akan damai (sakinah) dan penuh rasa cinta kasih (warahmah) apabila agama mewarnai kehidupan berkeluarga. Keempat, keyakinan dan kepercayaan pada Allah Swt. akan menjadi benteng keutuhan rumah tangga. Terakhir, permasalahan dalam rumah tangga akan diselesaikan melalui pendekatan agama. Sebab, apabila seseorang memiliki nilai spiritual maka ketika ia menghadapi masalah, ia tahu bahwa permasalahan tersebut harus dikembalikan pada Allah dan Rasul-Nya atau mencari solusinya dengan Alquran.

Beberapa penelitian sebelumnya lebih banyak membahas spiritual leadership yang berkaitan dengan beragam konteks, namun belum ada penelitian yang secara khusus melakukan eksplorasi spiritual leadership dalam konteks kehidupan berkeluarga. Hal ini berkaitan dengan kepala keluarga yang menjadi penentu kualitas anggota keluarga tersebut. Dengan demikian, apabila seorang kepala keluarga memiliki tingkat spiritual leadership yang baik maka keluarga tersebut akan terhindar dari masalah seperti perceraian dan kekerasan dalam keluarga, sehingga akan memengaruhi hal-hal ke depannya baik dalam dunia pendidikan, dunia pekerjaan dan lain sebagainya. Segala sesuatu yang terjadi bermula dari bagaimana sikap dan tindakan seorang kepala keluarga terhadap keluarganya, apabila kepala keluarga mampu menerapkan apa yang seharusnya dilakukan oleh seorang kepala keluarga maka kehidupan keluarga tersebut akan lebih baik daripada seorang kepala keluarga yang memiliki tingkat spiritual leadership rendah. Penelitian ini dilakukan untuk membuat sebuah model pengukuran kepemimpinan spiritual dalam konteks keluarga.

\section{Metode}

Pengembangan alat ukur yang dilakukan dalam penelitian ini menggunakan teori spiritual leadership dari Fry (2003), yang terdiri dari lima dimensi yaitu vision, altruistic love, hopel faith, meaning dan membership. Dimensi meaning merupakan turunan dari vision, begitu pula dengan dimensi membership merupakan turunan dari dimensi altruistic love (Fry, 2003). Peneliti mengembangkan sebuah alat ukur spiritual leadership yang diturunkan dari teori tersebut dengan jumlah item final sebanyak 26 item yang dimodifikasi dan dibuat berdasarkan pengembangan modifikasi alat ukur psikologis dan memenuhi properti psikometris yang ada (Ramdani, 2018). Enam item mewakili dimensi vision, sepuluh item mewakili dimensi altruistic love, lima item mewakili dimensi hope, dua item mewakili dimensi meaning dan tiga item mewakili dimensi membership.

Langkah-langkah yang dilakukan dalam pembuatan alat ukur spiritual leadership yang dilakukan oleh peneliti adalah mengungkap fenomena yang terjadi dalam kehidupan seharihari, menentukan grand theory, menentukan dimensi dan indikator, membuat item-item, meminta pendapat rater, melakukan fiksasi 
item, pengambilan data, serta menguji data dengan program statistik (Salsabila dkk., 2019).

Partisipan dalam penelitian ini adalah 405 kepala keluarga yang berada di daerah Jawa Barat, khususnya Bandung. Jumlah kepala keluarga berjenis kelamin laki-laki sebanyak 261 orang $(64.4 \%)$ dan perempuan sebanyak 144 orang $(35.6 \%)$. Kepala keluarga yang dimaksudkan dalam penelitian ini adalah seorang ayah, seorang ibu (jika ayah telah meninggal), bahkan bisa juga seorang anak tertua dalam suatu keluarga (jika ayah dan ibu telah meninggal). Sebagian besar usia partisipan penelitian adalah 40 tahun.

Teknik pengambilan sampel menggunakan non-probability sampling yaitu dengan metode purposive sampling, dimana kepala keluarga yang terjangkau dan bersedia menjadi partisipan penelitian ini akan mengisi kuesioner secara online. Alat ukur yang diisi oleh partisipan penelitian dalam bentuk google form atau kuesioner online. Data yang didapatkan dianalisis menggunakan model unidimensional confirmatory factor analysis (CFA) menggunakan program Lisrel.

\section{Hasil}

Penelitian ini dimulai dari peneliti mengembangkan 126 item untuk mengukur spiritual leadership. Sebanyak 126 item yang dikembangkan, diujicobakan kevalidannya kepada sepuluh orang rater yang merupakan pakar dari spiritual leadership (Aiken, 1985). Dari 126 item tersebut, dilakukan pengujian validitas Aiken/ validitas oleh rater, dimana 70 item digugurkan oleh rater. Tersisa 56 item yang akan dilakukan pengujian oleh program statistik. Dari 56 item yang tersisa, peneliti melakukan uji reliabilitas menggunakan cronbach alpha, hasil yang didapatkan adalah tersisa 26 item dari 56 item. Hasil uji reliabilitas yang didapatkan sangat baik, yakni $\alpha=.914$ dengan nilai yang cukup baik > .3 (Azwar, 2015), maka item yang lolos dan perlu diwaspadai bisa dilihat pada tabel 1.

Hasil analisis daya beda pada item alat ukur maka didapati bahwa terdapat 25 item yang memiliki kemampuan daya beda yang baik dan 1 item yang perlu diwaspadai karena memiliki kemampuan daya beda <.3, yaitu item 19. Akan tetapi, karena penelitian ini merupakan pengembangan alat ukur yang baru. Item 19 dianggap sebagai item yang perlu diwaspadai saja, bukan termasuk item yang tidak valid (Salsabila dkk., 2019).

Selanjutnya pada penelitian ini dilakukan uji CFA menggunakan program Lisrel dengan model unidimensional. Pemilihan model unidimensional disebabkan ada dimensi yang tidak terwakili, dalam arti apabila suatu dimensi memiliki kurang dari tiga item dalam pengukurannya, maka program tidak dapat dirunning (Salsabila dkk., 2019). Salah satu dimensi yang hilang dari lima dimensi dalam penelitian ini adalah dimensi meaning, karena hanya diwakili oleh dua item. Hasil pengujian model unidimensional pertama dapat dilihat pada gambar 1 (dimensi vision).

Tabel 1

Daya Beda Item Spiritual Leadership

\begin{tabular}{ccc}
\hline $\begin{array}{c}\text { No. } \\
\text { Item }\end{array}$ & $\begin{array}{c}\text { Corrected Item- } \\
\text { Total Correlation }\end{array}$ & Hasil \\
\hline 1 & .511 & Item Baik \\
2 & .494 & Item Baik \\
3 & .529 & Item Baik \\
4 & .450 & Item Baik \\
5 & .610 & Item Baik \\
6 & .542 & Item Baik \\
7 & .509 & Item Baik \\
8 & .573 & Item Baik \\
9 & .564 & Item Baik \\
10 & .606 & Item Baik \\
11 & .615 & Item Baik \\
12 & .549 & Item Baik \\
13 & .591 & Item Baik \\
14 & .576 & Item Baik \\
15 & .605 & Item Baik \\
16 & .575 & Item Baik \\
17 & .483 & Item Baik \\
18 & .609 & Item Baik \\
19 & .290 & Item Perlu diwaspadai \\
20 & .537 & Item Baik \\
21 & .540 & Item Baik \\
22 & .613 & Item Baik \\
23 & .479 & Item Baik \\
24 & .543 & Item Baik \\
25 & .416 & Item Baik \\
26 & .601 & Item Baik \\
\hline & &
\end{tabular}

JPIB : Jurnal Psikologi Islam dan Budaya, April 2020, Vol.3 No.1 


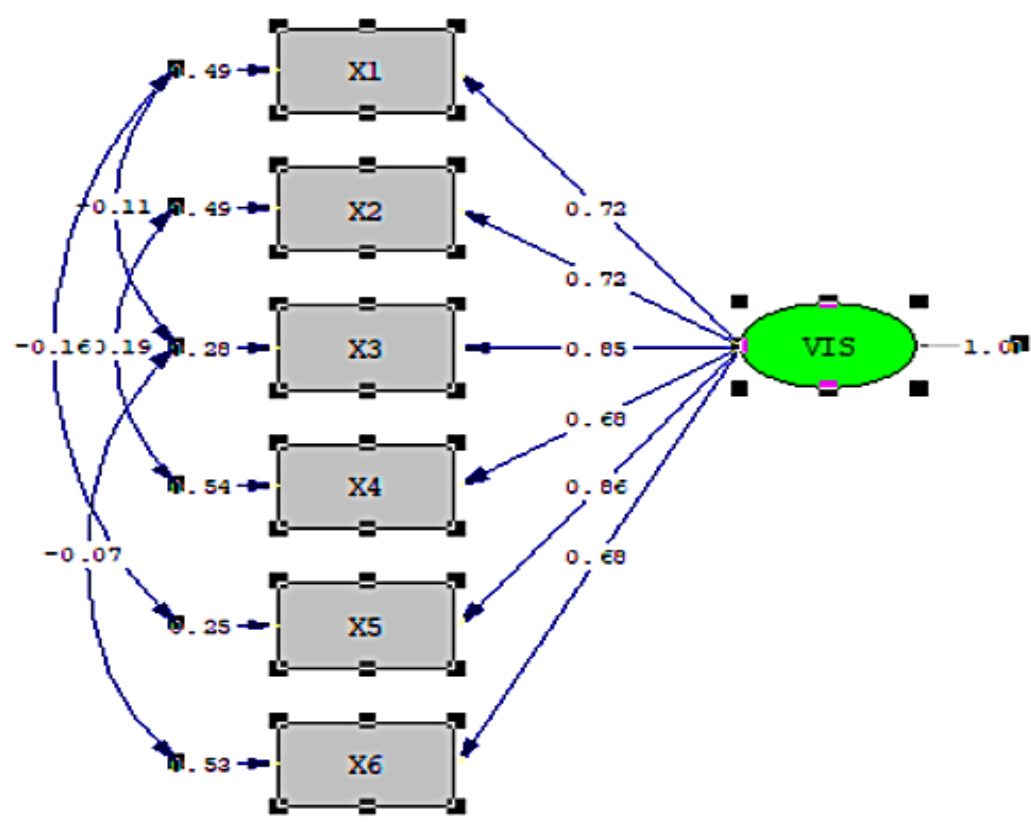

Chi-Square $=8.61, \mathrm{df}=5, \mathrm{P}$-value $=0.12570, \mathrm{RMSEA}=0.042$

Gambar 1. Model unidimensional untuk dimensi vision

Pada gambar 1, informasi statistik yang bisa diperoleh adalah nilai Chi-Square $=8.61, p$ value $>.05, d f=5$ dan RMSEA $<.05$. Hasil tersebut menunjukkan model pengukuran yang dilakukan untuk mengukur dimensi vision adalah cocok atau sesuai mengukur hal apa yang diukur. Enam item yang mengukur vision memiliki nilai factor loading > .3, artinya seluruh item valid mengukur vision. Bila dilihat pada gambar 1, diketahui terdapat empat bentuk modifikasi model atau kesalahan pengukuran. Namun menjadi hal yang wajar dalam suatu penganalisisan memiliki empat kesalahan pengukuran. Item 1 sampai dengan item 6 merupakan item yang valid.

Berdasarkan gambar 2 diketahui nilai ChiSquare $=42.96, p$-value $<.05, d f=24$, dan RMSEA < .05. Pada model pengukuran altruistic love nilai p-value yang dihasilkan kurang dari .05, seharusnya lebih besar dari 05 . Namun untuk mengambil keputusan bahwa model fit, tidak hanya berdasarkan satu kriteria p-value saja, dapat juga dilihat dari kriteria lainnya, yakni RMSEA < .05. Model dimensi altruistic love memiliki nilai RMSEA $<.05$, dapat diartikan bahwa model pengukuran altruistic love adalah fit, yang mana sepuluh item yang diujikan valid mengukur altruistic love. Nilai factor loading untuk seluruh item lebih besar dari .3 artinya item 7 sampai item 16 valid.

Berdasarkan hasil analisis dimensi hope/ faith, pada gambar 3, diketahui nilai Chi-Square $=.52, d f=2, p$-value $>.05$ dan RMSEA < .05 artinya model pengukuran dimensi hopel faith yang diujikan fit. Lima item yang diujikan pada model ini pun memiliki nilai factor loading lebih besar dari .3, artinya kelima item yang diujikan valid mengukur dimensi hope. Terdapat tiga kesalahan pengukuran dalam model ini, yaitu item 17 dan item 19, item 18 dan item 21, item 18 dan item 19. Kesalahan pengukuran yang terjadi merupakan hal yang wajar terjadi. Terkecuali, apabila ada item yang melakukan kesalahan pengukuran lebih dari tiga kali, maka item tersebut harus dibuang dalam pengukuran. Item 17 sampai dengan 21 valid.

Pengujian model fit pada dimensi membership (gambar 4) pun menghasilkan nilai Chi-Square $=.00, p$-value $>1, d f=0$ dan RMSEA < .05 . Artinya model yang diujikan sesuai dengan dimensi yang diukur, yakni ketiga item yang diujikan mengukur dimensi membership. Item 24 sampai dengan item 26 merupakan item yang valid. Dapat disimpulkan 


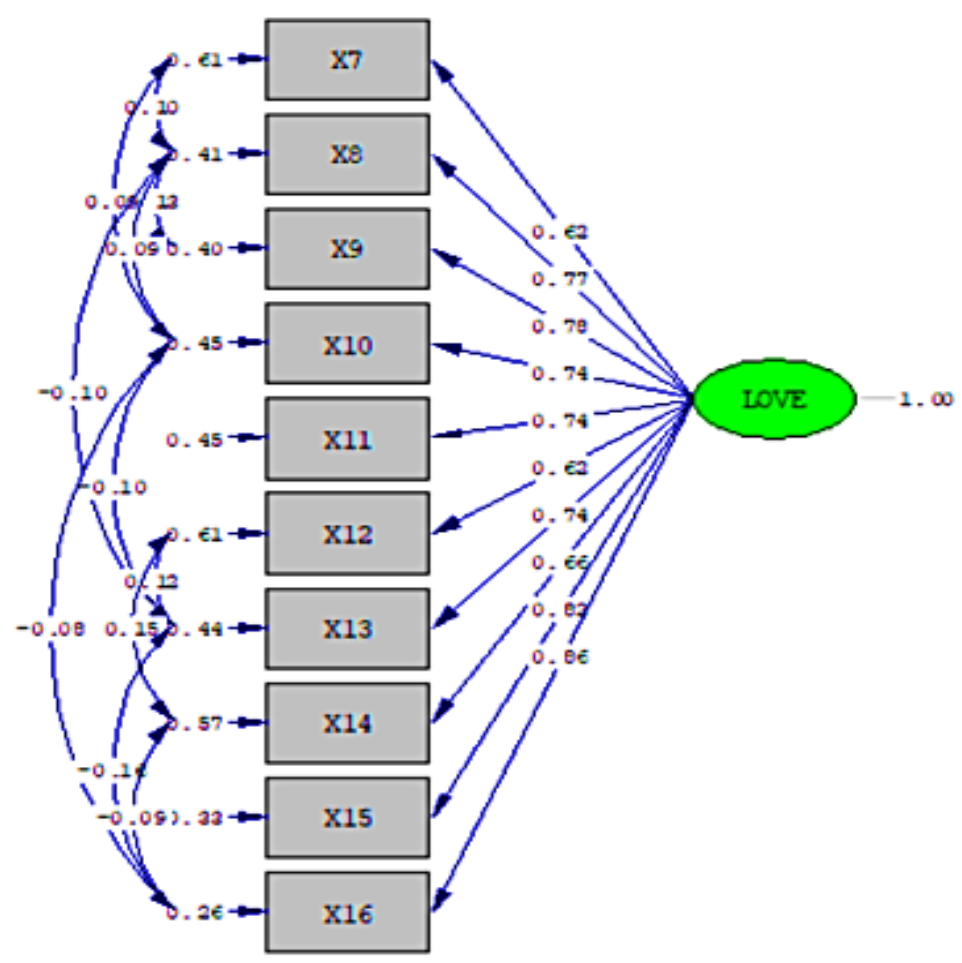

Chi-Square $=42.96, \mathrm{df}=24, \mathrm{P}$-value $=0.01007, \mathrm{RMSEA}=0.044$

Gambar 2. Model unidimensional untuk dimensi altruistic love

bahwa 26 item yang diujikan valid mengukur dimensi yang ingin diukur.

Setelah pengujian alat ukur dilakukan, peneliti mencoba melakukan kategorisasi partisipan penelitian menjadi tiga kelompok, yakni spiritual leadership yang tinggi, sedang dan rendah. Untuk kelompok rendah dihitung dengan formula $(\mathrm{X}<(\mathrm{M}-1 * \mathrm{SD})$, untuk kelompok sedang $(\mathrm{M}-1 * \mathrm{SD})<\mathrm{X}<(\mathrm{M}+1 * \mathrm{SD})$ dan kelompok tinggi $(\mathrm{X}>(\mathrm{M}+1 * \mathrm{SD})$. Hasil kategorisasi didapatkan 54 orang kepala keluarga yang memiliki nilai spiritual leadership tinggi, 296 orang kepala keluarga yang memiliki nilai spiritual leadership sedang, dan 55 orang kepala keluarga dengan nilai spiritual leadership rendah.

Sebagai analisis pembanding, peneliti melakukan uji confirmatory factor analysis dengan menggunakan 100 partisipan menggunakan program Partial Least Square (PLS) pada 26 item yang diujikan. Program PLS yang digunakan peneliti adalah program free download, dengan kapasitas menganalisis 100 responden. Dari hasil analisis menggunakan PLS didapatkan nilai reliabilitas setiap dimensi, untuk dimensi vision didapatkan nilai $\alpha=.722$, dimensi altruistic love $\alpha=.854$, dimensi hope/ faith $\alpha=.636$, dan dimensi membership $\alpha=.567$.

\section{Diskusi}

Alat ukur kepemimpinan spiritual yang dimodifikasi dalam penelitian ini didasarkan pada konsep teoretis yang sudah komprehensif sejak dikembangkan oleh Fry (2003) pada beberapa dekade yang lalu. Asumsi tersebut menekankan peneliti saat ini bahwa alat ukur yang dibuat harus mempertimbangkan aspekaspek spesifik yang tidak dijelaskan secara garis besar dalam penelitian sebelumnya. Hal ini membuat peneliti melakukan telaah mendalam supaya setiap item yang dibuat tidak menyalahi konstruk dan konteks penelitian terdahulu.

Bukti empiris kesesuaian antara teori yang ditegaskan oleh Fry (2003) dengan hasil modifikasi peneliti tersebut kemudian bisa dilihat pada hasil uji validasi rater yang 


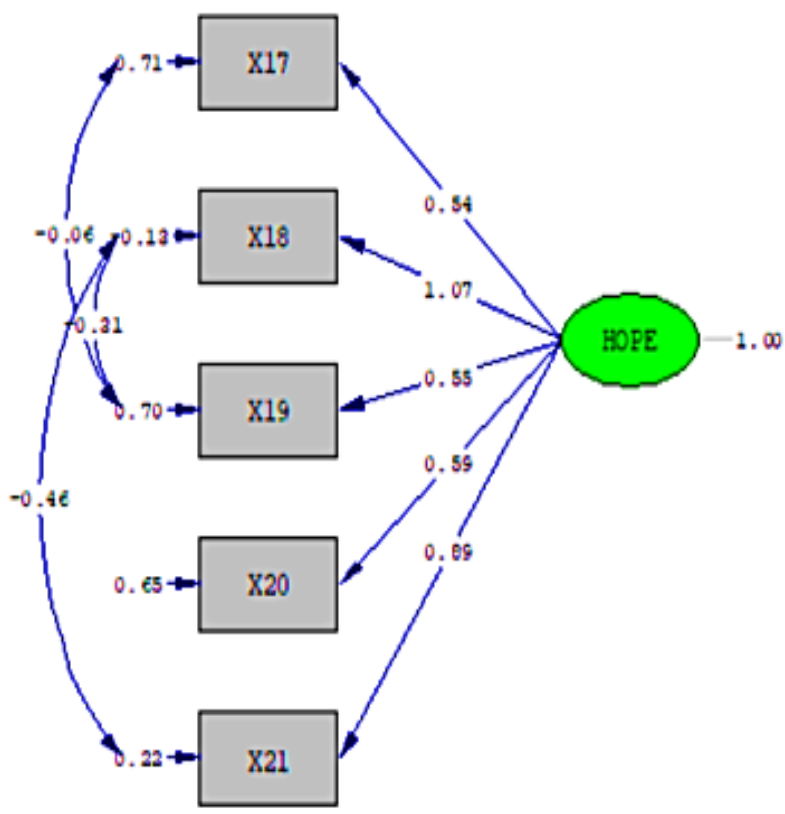

Chi-Square $=0.52, \mathrm{df}=2, \mathrm{P}$-value $=0.76641, \mathrm{RMSEA}=0.000$

Gambar 3. Model unidimensional untuk dimensi hope/ faith

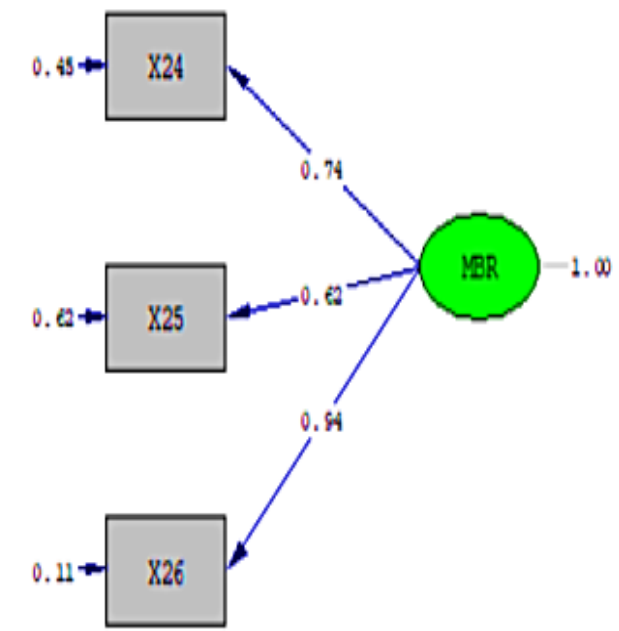

Chi-Square $=0.00, \mathrm{df}=0, \mathrm{P}$-value $=1.00000, \mathrm{RMSEA}=0.000$

Gambar 4. Model unidimensional untuk dimensi membership

menghasilkan sebanyak 56 item yang telah melalui proses pengujian validasi isi. Secara proporsi jumlah item yang bisa lolos dalam tahap tersebut masih dalam jumlah yang banyak artinya masih mewakili 50\% dari total item yang dibuat sehingga jumlah ini cukup untuk dilanjutkan pada pengujian selanjutnya. Hasil pada uji rater tersebut dikuatkan oleh beberapa penelitian terdahulu yang menyatakan bahwa koherensi yang baik antara teori dan item yang dibuat memungkinkan peneliti akan mendapat- kan item-item yang baik dan bisa digunakan efektif dalam penelitian (Ramdani dkk., 2018).

Uji daya beda merupakan tahapan selanjutnya yang harus dilakukan dalam memperkuat item yang sudah dibuat pada tahap modifikasi ini. Mengacu pada asumsi yang disampaikan oleh Azwar (2015) mengenai kualitas daya beda item. Mayoritas item yang dibuat dalam studi ini mempunyai kriteria item yang baik, dimana mereka mampu membedakan mana individu yang mempunyai kepemimpinan 
spiritual tinggi dan mana yang rendah. Dengan demikian, pada tahap daya beda, item-item berhak untuk dilanjutkan pada pengujian konstruk untuk melihat model yang dibangun apakah sesuai atau tidak.

Uji model yang dilakukan peneliti mengacu pada pengujian model yang mengikuti prosedur ilmiah yang dikembangkan dalam produk Lisrel. Berdasarkan pada hasil yang disampaikan pada model di bagian sebelumnya, ada 4 model dimensi yang menghasilkan pengukuran fit dalam penelitian yaitu vision, altruistic love, hopel faith, dan membership. Hanya ada satu dimensi yang gugur dalam penelitian yaitu dimensi meaning yang dalam penelitian ini tidak layak untuk digabungkan dengan dimensi lainnya.

Kurangnya dimensi meaning menghasilkan model yang fit disebabkan oleh beberapa faktor yang pada dasarnya secara psikometris seharusnya bisa diantisipasi oleh peneliti sejak awal. Secara teoretis dimensi meaning mempunyai asumsi yang hampir sama dengan dimensi altruistic love, dimana menurut Fry (2003), orang bisa saja menjadi sangat memahami apa yang terjadi di lingkungannya dan dirinya (meaning), karena mereka sudah mempunyai karakteristik altruistic love dalam kepribadiannya, sehingga dua dimensi ini dianggap saling overlap dalam manifestasinya. Faktor-faktor tersebut diantaranya adalah sifat overlap dari item-item yang dibuat dalam dimensi tersebut sehingga tidak cukup kuat untuk menjelaskan independensi dimensi dengan item secara linier (Salsabila dkk., 2019). Faktor lainnya juga didasarkan pada pengalaman konstruksi alat ukur lainnya yang menyebutkan bahwa ketidak-fit-an model dalam dimensi tersebut karena variasi jawaban dalam item-item tersebut tidak serta merta cukup kuat merepresentasikan jawaban responden yang sesungguhnya (Augustiya dkk., 2019; Salsabila dkk., 2019).

Untuk penelitian lebih lanjut, hasil studi ini menyarankan penggunaan alat ukur yang dikembangkan oleh peneliti dengan lebih memperbanyak jumlah partisipan serta memperluas jangkauan wilayah partisipan.
Beberapa keterbatasan dalam penelitian ini diantaranya, waktu penelitian yang relatif singkat, kurang tajamnya pemahaman peneliti terhadap konstruk psikologi yang diteliti, serta kurang spesifiknya dalam menetapkan kriteria partisipan. Sebaiknya dilakukan penelitian yang berfokus pada satu status yaitu kepala keluarga yang merupakan seorang ayah.

\section{Simpulan}

Berdasarkan hasil penelitian pengembangan alat ukur spiritual leadership dapat disimpulkan bahwa dari lima dimensi yang diukur, terdapat satu dimensi yang gugur dalam pengujian, yakni dimensi meaning. Empat dimensi lainnya, yaitu vision, altruistic love, hopel faith, dan membership dapat terukur oleh 26 item yang valid dan reliabel berdasarkan uji confirmatory factor analysis dan cronbach alpha. Alat ukur yang dikembangkan ini dapat digunakan kembali untuk penelitian selanjutnya.

\section{Referensi}

Afsar, B., Badir, Y., \& Kiani, U. S. (2016). Linking spiritual leadership and employee pro-environmental behavior: The influence of workplace spirituality, intrinsic motivation, and environmental passion. Journal of Environmental Psychology, 45, 79-88.

https://doi.org/10.1016/j.jenvp.2015.11.01 1

Aiken, L. (1985). Three coefficients for analysing reliability and validity of rating. Educational and Psychological Measurement, 45, 131-142. https://doi.org/10.1177/073998638700920 05

Augustiya, T., Nurislamiaty, Q., Al-fatoni, M. D., \& Rachma, L. N. (2019). Hubungan orientasi karier dengan optimisme pada mahasiswa jurusan keagamaan UIN Sunan Gunung Djati Bandung. Jurnal Psikologi Islam dan Budaya, 2(1), 31-42. https://doi.org/10.15575/jpib.v2i1.4014

Ayranci, E., \& Semercioz, F. (2011). The relationship between spiritual leadership 
and issues of spirituality and religiosity: a study of top Turkish managers. International Journal of Business and Management, $6(4)$. https://doi.org/10.5539/ijbm.v6n4p136

Azwar, S. (2015). Validitas dan reliabilitas. Pustaka Belajar.

Bastaits, K., Pasteels, I., \& Mortelmans, D. (2018). How do post-divorce paternal and maternal family trajectories relate to adolescents' subjective well-being? Journal of Adolescence, 64(December 2016), 98 108.

https://doi.org/10.1016/j.adolescence.2018. 02.005

Benefiel, M. (2005). The second half of the journey: Spiritual leadership for organizational transformation. Leadership Quarterly, 16(5), 723-747. https://doi.org/10.1016/j.leaqua.2005.07.00 5

Chen, C. Y., \& Li, C. I. (2013). Assessing the spiritual leadership effectiveness: The contribution of follower's self-concept and preliminary tests for moderation of culture and managerial position. Leadership Quarterly, 24(1), 240-255. https://doi.org/10.1016/j.leaqua.2012.11.00 4

Doehring, C. (2019). Using spiritual care to alleviate religious, spiritual, and moral struggles arising from acute health crises. Ethics, Medicine and Public Health, 9, 6874.

https://doi.org/10.1016/j.jemep.2019.05.00 3

Fridayanti. (2015). Religiusitas, spritualitas dalam kajian psikologi dan urgensi perumusan religiusitas islam. Psympathic: Jurnal Ilmiah Psikologi, 2(2). https://doi.org/10.15575/psy.v2i2.460

Fry, L. W. (2003). Toward a theory of spiritual leadership. Leadership Quarterly, 14(6), 693-727.

https://doi.org/10.1016/j.leaqua.2003.09.00 1

Fry, L. W., Vitucci, S., \& Cedillo, M. (2005). Spiritual leadership and army transformation: Theory, measurement, and establishing a baseline. Leadership Quarterly, 16(5), 835-862. https://doi.org/10.1016/j.leaqua.2005.07.01 2

Jaenudin, U., \& Tahrir, T. (2019). Studi religiusitas, budaya sunda, dan perilaku moral pada masyarakat kabupaten Bandung. Jurnal Psikologi Islam dan Budaya, 2(1), 1-8. https://doi.org/10.15575/jpib.v2i1.3445

Kardinah, N. (2009). Keluarga dan problematikanya menuju keluarga sakinah (Tinjauan dalam perspektif marrital psikologi). Psympathic: Jurnal Ilmiah Psikologi, 1(1), 109-120. https://doi.org/10.15575/psy.v1i1.2171

Kaya, A. (2015). The relationship between spiritual leadership and organizational citizenship behaviors: A research on school principals' behaviors. Educational Sciences: Theory \& Practice, 15(3), 597606. https://doi.org/10.12738/estp.2015.3.1988

Krisharyuli, M., Himam, F., \& Ramdani, Z. (2020). Ethical leadership: Conceptualization and measurement. Journal of Leadership in Organizations, 2. https://jurnal.ugm.ac.id/leadership

Mediawati, D., Arifin, B. S., \& Supriyatin, T. (2012). Hubungan dukungan keluarga terhadap penyesuaian diri pada pasien psikotik resosialisasi di panti sosial bina laras phala martha Sukabumi. Psympathic: Jurnal Ilmiah Psikologi, 5(2), 602-615.

Polat, S. (2011). The level of faculty members' spiritual leadership (SL) qualities display according to students in faculty of education. Procedia - Social and Behavioral Sciences, 15, 2033-2041. https://doi.org/10.1016/j.sbspro.2011.04.04 9

Ramdani, Z. (2018). Construction of academic integrity scale. International Journal of Research Studies in Psychology, 7(1), 8797. https://doi.org/10.5861/ijrsp.2018.3003

Ramdani, Z., Supriyatin, T., \& Susanti, S. (2018). Perumusan dan pengujian 
instrumen alat ukur kesabaran sebagai bentuk coping strategy. Jurnal Psikologi Islam dan Budaya, 1(2), 97-106.

Royanulloh, R., \& Komari, K. (2019). Bulan ramadan dan kebahagiaan seorang muslim. Jurnal Psikologi Islam dan Budaya, 2(2), 51-62.

https://doi.org/10.15575/jpib.v2i2.5587

Saad, M., See, T. P., Adil, M. A. M., \& Kassim, N. M. (2015). Spiritual intelligence on leadership effectiveness and food-hygiene practices in public institutions. Procedia Social and Behavioral Sciences, 201(February), 146-155. https://doi.org/10.1016/j.sbspro.2015.08.16 1

Salsabila, D. F., Rofifah, R., Natanael, Y., \& Ramdani, Z. (2019). Uji validitas konstruk indonesian-psychological measurement of islamic religiousness (I-PMIR). Jurnal Psikologi Islam dan Budaya, 2(2), 1-10. https://doi.org/10.15575/jpib.v2i2.5494

Šilingienè, V., \& Škèrienè, S. (2015). Expression of leaders' spiritual intelligence in a context of service organizations: A gender approach. Procedia - Social and Behavioral Sciences, 213, 758-763. https://doi.org/10.1016/j.sbspro.2015.11.46 7

Smith-Greenaway, E., \& Clark, S. (2017). Variation in the link between parental divorce and children's health disadvantage in low and high divorce settings. SSM Population Health, 3, 473-486. https://doi.org/10.1016/j.ssmph.2017.04.00 4
Stokkebekk, J., Iversen, A. C., Hollekim, R., \& Ness, O. (2019). "Keeping balance", "Keeping distance" and "Keeping on with life": Child positions in divorced families with prolonged conflicts. Children and Youth Services Review, 102(January), 108119.

https://doi.org/10.1016/j.childyouth.2019.0 4.021

Sumanty, D., Sudirman, D., \& Puspasari, D. (2018). Hubungan religiusitas dengan citra tubuh pada wanita dewasa awal. Jurnal Psikologi Islam dan Budaya, 1(1), 9-28. https://doi.org/10.15575/jpib.v1i1.2076

Tkaczynski, A., \& Arli, D. (2018). Religious tourism and spiritual leadership development: Christian leadership conferences. Journal of Hospitality and Tourism Management, 35, 75-84. https://doi.org/10.1016/j.jhtm.2018.03.004

Weinberg, F. J., \& Locander, W. B. (2014). Advancing workplace spiritual development: A dyadic mentoring approach. Leadership Quarterly, 25(2), 391-408.

https://doi.org/10.1016/j.leaqua.2013.10.00 9

Wita, M. M. N. A., Khasanah, A. N., \& Rahayu, M. S. (2018). Tipe parental mediation dan adiksi internet siswa kelas V SD X Bandung. Psympathic: Jurnal Ilmiah Psikologi, 5(2), 221-230. https://doi.org/10.15575/psy.v5i2.3310 